\title{
Papers
}

\section{CRM software applications and business performance}

Received (in revised form): 2nd August, 2006

\section{Lawrence Ang}

is Senior Lecturer in Marketing at Macquarie Graduate School of Management, Macquarie University.

\section{Francis Buttle}

is Professor of CRM and Marketing at Macquarie Graduate School of Management, Macquarie University.

Keywords CRM software, CRM, ROI, business performance, customer acquisition, customer retention, customer development

\begin{abstract}
After a period of decline at the turn of the century, demand for customer relationship management (CRM) software is rebounding. Our investigation of the Australian context, however, shows that a large proportion of companies are still undeveloped in terms of their application of software to support their customer management strategies. Less than 40 per cent of companies use CRM software. When it is used, the software is more commonly deployed for customer retention and customer development purposes. It is less extensively used to support customer acquisition, but when this does happen it results in more cost-effective marketing campaigns. Companies that do employ CRM software are generally satisfied with their return on investment (ROI) from the software. Our data suggest that companies' level of satisfaction with software performance varies directly with its reported impact on business profitability. The performance of the software in meeting companies' expectations of customer retention is a statistically significant predictor of profitability. Larger companies tend to be less satisfied with software ROI, while service companies appear to be more likely to adopt CRM software than companies in other sectors. We find that the intelligent application of CRM software can yield improvements in business performance.

Journal of Database Marketing \& Customer Strategy Management (2006) 14, 4-16.

doi:10.1057/palgrave.dbm.3250034
\end{abstract}

\section{INTRODUCTION}

Companies have access to an abundance of customer-related information in ways that were unimaginable a couple of decades ago. An ability to extract high-quality usable information in a timely manner is increasingly important, particularly given a marketing environment of fragmented communications media, and of sophisticated technologies such as mobile messaging, web-based supply chains and e-commerce. ${ }^{1}$ As a result, companies are becoming more dependent on software to convert information into actionable intelligence, and to communicate that intelligence to customer touch-points in a timely manner. Customer management software is an important component of both analytical and operational customer relationship management (CRM) implementations. But 
how do companies use CRM software to support their customer management activities, and how satisfied are they with the results they experience? Importantly, is the implementation of this software associated with enhanced business performance? These questions are the focus of our paper.

\section{What is CRM and CRM software?}

CRM is a business practice that has been defined as follows:

CRM is the core business strategy that integrates internal process and functions, and external networks, to create and deliver value to targeted customers, at a profit. It is grounded on high quality customer data and enabled by IT. ${ }^{2}$

The application of information technology (IT) is a distinguishing attribute of CRM, particularly in its operational and analytical forms. ${ }^{3}$ Operational CRM relies on software to automate selling, marketing and service processes. Operational software applications include salesforce automation (SFA), campaign management, event-based marketing, opportunity management, product configuration and contact management solutions, inter alia. Analytical CRM is enabled by engines such as Enterprise Miner from SAS Institute and 7i Business Intelligence from MicroStrategy. Analytical CRM software explores customer-related data to answer questions such as 'what should we offer this customer next?', 'what is this customer's propensity to churn?' or 'how can our customers be segmented for campaigning purposes?' In general, CRM software applications help companies manage their customer relationships more efficiently and effectively. But as captured in our chosen CRM definition, we, like others do recognise that CRM is not simply about technology alone. $^{4,5}$

The market for CRM software is rebounding. The Gartner Group reported

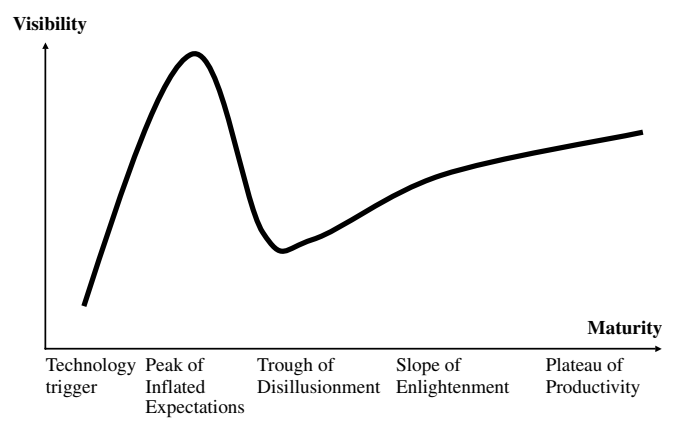

Figure 1: The Hype Cycle (Source: The Gartner Group, 2005)

that CRM software licence revenues had fallen 15 per cent in $2002 .{ }^{6}$ They estimated that revenues would recover to 5 per cent CAGR through to 2007, driven by economic recovery and increased competition. In similar vein, AMR Research estimated that CRM software sales grew by 6 per cent in $2004 .^{7}$ This rebound may also signify the influence of the Technology Hype cycle, which shows how companies finally come to understand and benefit from CRM after earlier periods of overenthusiasm and disappointment (Figure 1). ${ }^{8}$ Technology costs are not the only costs that CRM implementations incur. Forrester Research estimated that although $\$ 3.2$ billion would be spent on CRM software worldwide in 2005, more than three times this amount, or $\$ 9.8$ billion would be spent on software integration, administration and maintenance. $^{9}$

\section{LITERATURE REVIEW}

Much of the research into CRM implementation tends to focus either on its alleged failure to deliver business benefits, or the enabling and disabling conditions that impact on CRM performance. Sweat, ${ }^{10}$ for example, reported failure rates of between 25 and 80 per cent. Overly expensive investment in technology — both software and hardware - is cited as a significant cause of CRM's failure to deliver value. ${ }^{11}$ People issues are also implicated in the failure of CRM implementations. McKinsey 
reported that 59 per cent of companies who were successful in their CRM implementations addressed cultural change issues compared to 33 per cent of those who failed. ${ }^{12}$ More recently, Iriana and Buttle $^{13}$ found that companies that promote an atmosphere of innovation or risk taking, hence creating a climate for employees to act in the best interest of customers tend to fare better in their CRM outcomes. But very little has been published about the deployment of CRM software, and its impact on company performance. In fact, the whole area is so under-researched, that it has been earmarked by the Marketing Science Institute to be a priority research area. ${ }^{14}$

\section{SFA software}

During the early 1990s, the CRM software market was dominated by SFA applications. This remains a core component in CRM software suites. Rackman ${ }^{15}$ has argued that we should review what we have learnt about the adoption of SFA in order not to make the same mistake with CRM software more broadly. History shows that success rates of SFA implementations may not be as high as vendors would wish. One study estimates this to be around 50 per cent. ${ }^{16}$ Others are even more pessimistic, reporting failure rates of between 60 and 75 per cent. ${ }^{17,18,19}$ Where successes are reported, they tend to occur several years after adoption. For example, Erffmeyer and Johnson $^{20}$ in a sample of 43 companies found that up to 85 per cent of management and 80 per cent of the salesforce were 'very' or 'somewhat satisfied' (ie, top two boxes in a 5-point scale) with their SFA. Their sample had an average of 6.4 years of implementation experience.

Just as disappointing are the results of a study by Speier and Ventakash. ${ }^{21}$ They surveyed two companies across three time periods: (i) immediately after their SFA training, (ii) three months after implementation and then (iii) six months after implementation. Not only did they discover that SFA failed to contribute significantly to any increase in the number of sales contracts or sales volumes, but they also found that it was instrumental in causing sales people to leave the company after 6 months. In a qualitative in-depth investigation of three companies Bush et al. ${ }^{22}$ found that only one company (a global communication services provider) was prepared to say that their SFA has been a success, and then only after 5 years of implementation. Even so, all the respondents found it difficult to define and explain what specific value the SFA delivered to their salespeople.

\section{CRM software}

Literature in the area of CRM software has tended to centre on software package or vendor reviews, ${ }^{23}$ or case studies about its implementation. ${ }^{24}$ One case study into three companies concluded that one of the main concerns in adopting CRM software is that it is perceived to come in a 'one size fits all' package. ${ }^{25}$ This is fuelled by the fact that vendors tend to have a standardised view of what relationship management process should be, creating problems in flexibility and functionality.

Two recent academic studies have begun to shed light on the impact of CRMrelated technologies on company performance. Based on a sample of 172 US companies, split 50:50 between goods manufacturers and service organisations, Jayachandran et al. found that companies with relational information management processes (ie, they have interactive customer contact, from which customer information is captured, integrated and widely deployed and used across the business) tend to experience better customer satisfaction and customer retention outcomes. Furthermore, this association is even stronger when the company's CRM system is capable of frontoffice activities across the sales, marketing and service functions. ${ }^{26}$ 
In contrast, Reinartz et al. found a negative relationship between CRM technologies and the economic performance of firms. From a sample of 211 Swiss, German and Austrian companies across five industries (hospitality, power utilities, financial services and online retailing), they found that the more sophisticated companies are in their CRM technologies, the worse is their economic performance as judged subjectively by key informants. Furthermore, they found a significant interactive effect in that this negative relationship was most pronounced when companies were trying to initiate a relationship with customers (eg, customer acquisition or win-back of lost customers). ${ }^{27}$

In relation to our research objectives, it should be noted that these two studies do not directly evaluate the influence of CRM software, per se, but focus on the much broader issue of CRM-related technologies. Reinartz et al. chose company performance as their ultimate dependent variable, measuring this both objectively (using return on assets (RoA) data reported in the annual accounts), and subjectively (using key informants' assessments of overall performance, market share, growth and profitability). ${ }^{28}$ We believe that RoA is influenced by so many variables that it is not a useful dependent variable for the assessment of CRM-related investments. Neither of these two studies investigated the effects of CRM-related technologies on customer acquisition, retention and development outcomes. Rather, these activities were bundled together. We believe that customer acquisition, retention and development are strategically important business objectives in their own right, and merit assessment.

Finally, both these studies have chosen different ways of conceptualising and operationalising similar constructs. Jayachandran et al. ${ }^{29}$ use 42 items to measure CRM technologies, while their dependent variable is a composite index of customer satisfaction and customer retention. Reinartz et al. ${ }^{30}$ measure CRM-related technologies using only four items, with the dependent variable being company performance.

In summary, we are not aware of any academic study that looks at the performance of CRM software per se, rather than more broadly defined CRM technologies. Neither can we find any work that focuses on software's role in management of the customer lifecycle stages of acquisition, retention and development, user satisfaction with software return on investment (ROI) and the software's impact on business performance. Our aim is to fill this knowledge gap.

\section{HYPOTHESES DEVELOPMENT}

\section{ROI, satisfaction and business performance}

Other than vendor-produced case studies, very little has been written about ROI from, satisfaction with, and business outcomes associated with CRM software. These are important issues because they will affect CRM adoption. We will now review the extant literature on these issues before developing our hypotheses.

In one survey of senior executives across five continents (North and South America, Europe, Asia and Africa), Bain and Co. found that the use of CRM tools had increased from 35 to 78 per cent between 2000 and 2002. But satisfaction with the performance of these tools was below 50 per cent. ${ }^{31}$ But a more recent survey of 328 US IT executives by CIO Insight magazine found that satisfaction may be increasing 20 per cent said that their CRM deployment exceeded their expectations, 50 per cent said they met their expectations, while only 20 per cent said they were below expectations. ${ }^{32}$

Different authors provide conflicting views on the impact of CRM software on business performance. Thirty-one per cent of a sample of 202 projects reports that CRM software had improved their ability 
to sell and service their customers. ${ }^{33}$ Starkey and Woodcock ${ }^{34}$ claim that returns on CRM investments can be as high as 400 per cent over the full life of a CRM project. Woodcock's benchmarking study suggests a strong positive association $(r=0.80)$ between customer management expertise and business performance. Success is not guaranteed by simply adopting new software. Rather it depends on overcoming a host of barriers such as a lack of ownership among senior executives, lack of education, resistance from functional and departmental silos, and so on. ${ }^{35}$

Research into ROI from SFA implementations is also thin. According to Erffmeyer and Johnson, ${ }^{36}$ only 50 per cent of companies bother to formally evaluate the adoption of SFA, even when they have had the software in place for several years. In a more recent review of SFA in eight companies, Bush et al. ${ }^{37}$ found that only two had any sort of outcome measure in place. Only one of these was a business performance outcome.

Another investigation of SFA in both Europe and the USA reported that SFA helped companies lift their revenues by an average of $\$ 22$ million, even though the payback period was about $6-7$ years. ${ }^{38} \mathrm{~A}$ single-company case study conducted by Gillan $^{39}$ found that a $\$ 1.5$ million investment in SFA had a payback period of 18 months.

Finally, Wright and Donaldson ${ }^{40}$ in a survey of 72 banks in the UK found their use of SFA to be not very sophisticated and hence unlikely to lead to any significant improvement in the marketing outcomes of customer acquisition, retention and development.

One possible reason why there is a dearth of research into the ROI of CRM is because it is too difficult to assess objectively or experimentally. For example, Starkey et al. ${ }^{41}$ found that only 34 per cent of companies in Malaysia ( $n=34$ companies) had explicit key performance indicators for their CRM implementation. We suggest that there are three reasons why ROI is hard to evaluate: (i) delimiting the boundaries of CRM, (ii) defining the time-frame for assessment and (iii) agreeing on what constitutes investment and return. ${ }^{42}$ Our solution is to divide the CRM task into three different stages: customer acquisition, retention and development. Assessment of ROI can then be performed in the context of these three stages separately. Indeed, this is also a framework which can be deployed for estimation of customer value. $^{43}$

Similarly, we propose to evaluate the effectiveness of the software by assessing how well it is deployed across the three lifecycle stages. It follows that if the performance of the software exceeds the company's expectations in each of these three customer management activities, then logically, it should be reflected in higher satisfaction with the software's ROI performance. This should in turn impact positively on business outcomes, significant among which is enhanced company profitability (see Figure 2). Thus, we hypothesise:

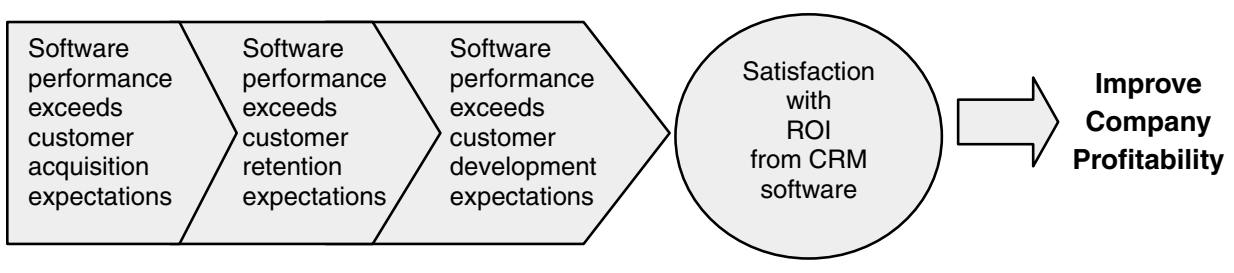

Figure 2: CRM software performance ROI model 
H1: There is a significant and positive relationship between satisfaction with the ROI delivered by CRM software and the performance of the software in exceeding company expectations of customer acquisition, retention and development.

$\mathrm{H} 2$ : There is a significant and positive relationship between satisfaction with the ROI delivered by CRM software and improvements in company profitability.

\section{Company size}

The size of the company may also be linked to satisfaction with the ROI generated by the adopted CRM software. Rivers and Dart ${ }^{44}$ found that larger companies with more salespeople tend to adopt SFA. This is consistent with other findings that larger companies are generally more willing to adopt IT than smaller companies. Starkey and Woodcock ${ }^{45}$ also found that larger companies tend to find managing their customers more difficult than smaller companies and hence were more likely to adopt CRM technologies. Thus, we hypothesise:

H3: Larger companies are significantly more likely to use the CRM software to assist in customer acquisition, retention and development than smaller companies.

But this does not mean that larger companies are necessarily more satisfied with the results of their adoption of CRM software. Larger companies may have to contend with more organisational issues that make software deployment and integration more difficult. Larger companies may also be more demanding of their CRM partners such as vendors and consultants. This implies that they may be more dissatisfied especially if they have invested significant sums in their CRM solutions. Larger companies may also have different customer management goals. Rigby, ${ }^{46}$ for instance, found that smaller companies are more focussed on growth than larger companies and are thus more sanguine about the use of management tools, including CRM, compared to larger companies who may be more focussed on cost cutting. This corroborates an earlier study in which Hendricks and Singhal ${ }^{47}$ found that smaller companies outperformed larger companies in terms of many growth-related metrics. In totality, all these lead to the following hypothesis:

\section{H4: Larger companies are more likely} to be dissatisfied with the ROI delivered by CRM software than smaller companies.

\section{Manufacturing and service companies}

The nature of a company's goods and services may also influence its use of, and satisfaction with, CRM software. It can be argued that service companies have a higher propensity to relationship-building than non-service companies. Because of their intangibility and variability, services are said to be higher in perceived risk than similarly priced goods. ${ }^{48}$ Risk is reduced for customers if they build a closer relationship with a trusted supplier. Service companies are therefore motivated to invest in relationship-building. Because of their higher levels of intangibility, services are also more readily customised. Customisation depends on the ability of the service provider to sense and respond to customers' different requirements. This creates a significant role for customer-specific insight, which can be gained through customer interaction. We therefore expect service companies to be more active in using the CRM software for the activities of customer acquisition, retention and development. Indeed, Starkey et al. ${ }^{49}$ found that credit 
card companies have the most sophisticated customer management practices. This leads to the following two hypotheses:

H5: Service companies are significantly more likely to use CRM software to assist in customer acquisition, retention and development than non-service companies.

H6: Service companies are more satisfied with the ROI delivered by CRM software than nonservice companies.

\section{METHODOLOGY}

\section{Sampling}

Our population of interest is Australian industry and commerce. A stratified random sample of 732 companies was contacted from the Dun and Bradstreet database of the top 1,000 companies in Australia. The population was stratified into three annual turnover groups: $\$ 50-\$ 99$ million, $\$ 100-$ $\$ 500$ million, and above $\$ 500$ million. The invitation to participate was addressed to the person in charge of customer relations. The incentive was a summary report of the study, which has now been fulfilled.

\section{Data collection}

We first contacted the 732 selected companies by telephone, across a period of 2 months. We asked to speak to the person in charge of marketing, and then more specifically the person/s in charge of customer acquisition, retention or development. Following agreement to participate, the instrument was mailed to the sample. A response rate of 23 per cent was achieved resulting in a sample size of 170 companies.

\section{Instrument development and data analysis}

Items in the instrument were developed from a literature review, and piloted and refined over several iterations. Some of the questions measuring independent variables were nominal in nature. These focussed on the use of CRM software to support three customer management activities acquisition, retention and development. Overall satisfaction with the ROI of the software was measured using a 7-point Likert scale, as was the extent to which the software met respondent expectations in supporting the three management goals of customer acquisition, retention and development.

The ultimate dependent variable was whether the CRM software had made a contribution to company profitability, again measured on 7-point scale with 7 anchored as 'a critical contribution' and 1 as 'no contribution'.

Sample questions used in this survey are found in Appendix.

\section{RESULTS}

\section{Response rate}

One hundred and seventy responses were obtained (23 per cent response rate). Forty-three reported annual turnover between $\$ 50$ - \$99 million, 46 were between $\$ 100-\$ 500$ million and 42 were above $\$ 500$ million. Thirty-nine companies declined to divulge their annual turnover. Participants represented all major standard industrial classification (ANZSIC) codes. Dominant sectors were manufacturing (43 companies); wholesale and retail (24) and health, community services, accommodation, cultural/recreation, personal and other services (23).

Table 1: Percentage reporting satisfaction with $\mathrm{ROI}$ from their CRM software

\begin{tabular}{lc}
\hline & $\boldsymbol{n = 6 7}(\%)$ \\
\hline Satisfied to very satisfied (5-7) & 40 \\
Midpoint (4) & 24 \\
Dissatisfied to very & 20 \\
dissatisfied (1-3) & \\
Don't know & 16 \\
Total & 100 \\
Mean & 4.5 \\
\hline
\end{tabular}




\section{Descriptive results}

Only 39 per cent of companies in our sample use CRM software. Of these, 40 per cent reported they were satisfied (above the midpoint 4) with the ROI the software generated, 24 per cent were lukewarm (midpoint) and 20 per cent were dissatisfied (below midpoint 4$)$. The mean across the sample $(n=67)$ was 4.5 (s.d.=1.54). A one-sample $t$-test reveals the mean to be significantly above 4 , the midpoint $(t=2.4$, $p<0.05)$, indicating a generally positive reporting of ROI (see Table 1).

Furthermore, 35 per cent of companies used CRM software to support their customer retention strategy; 31 per cent to support their customer development strategy; 29 per cent to support their customer acquisition strategy. But how satisfied are companies with this?

As shown in Table 2, 48 per cent of companies $(n=60)$ using CRM software to support customer retention reported that it had exceeded their expectations (points $5-7$ on the 7-point scale); 42 per cent of companies $(n=52)$ using CRM software to support customer development reported that the software exceeded their expectations; 33 per cent of companies $(n=49)$ using CRM software to support customer acquisition reported that the software exceeded their expectations. Overall, the sample reports that CRM software is more effective for supporting customer retention $($ mean $=4.5$, s.d. $=1.26)$ and customer development activities (mean $=4.6$, s.d. $=1.29)$ than customer acquisition $($ mean $=4.1$, s.d. $=1.27)$.
A one-sample $t$-test for the three means (4.1, 4.6 and 4.5) against the midpoint, 4, reveals significant differences for customer retention $(t=2.8, p<0.05)$ and development $(t=4.6, p<0.05)$ only. There is no significant difference between retention and development $(t=0.72, p>0.05)$.

\section{Bivariate and multivariate results}

In $\mathrm{H} 1$, we hypothesised a significant and positive relationship between satisfaction with the ROI delivered by CRM software and the performance of the software in exceeding company expectations of customer acquisition, retention and development. We tested this hypothesis by running a Pearson correlation between the two variables. The results in Table 3 support this hypothesis. The associations are all positive and statistically significant $(p<0.001)$ : customer retention expectations at $r=0.65$; customer development at $r=0.69$ and customer acquisition at $r=0.55$. H1 is thus supported.

In $\mathrm{H} 2$, we hypothesised a significant and positive relationship between satisfaction with the ROI delivered by CRM software and improvements in business profitability. Table 3 shows that this correlation is positive and significant $(r=0.48 ; p<0.01)$. Thus, H2 is supported.

We conducted additional analyses to establish which variables were the strongest predictors of company profitability. First, we converted all four independent variables (ROI satisfaction ratings, and expectations ratings for customer acquisition, retention and development) and the dependent variable (company profitability

Table 2: Percentage reporting that CRM software met, exceeded or fell short of expectations

\begin{tabular}{lccc}
\hline & $\begin{array}{l}\text { Acquisition \% } \\
(\boldsymbol{n}=\mathbf{4 9 )}\end{array}$ & $\begin{array}{l}\text { Retention \% } \\
(\boldsymbol{n}=\mathbf{6 0 )}\end{array}$ & $\begin{array}{l}\text { Development \% } \\
(\boldsymbol{n}=\mathbf{5 2})\end{array}$ \\
\hline Exceeded expectations (5-7) & 33 & 48 & 42 \\
Met expectations (4) & 25 & 17 & 21 \\
Below expectations (1-3) & 28 & 17 & 15 \\
Don't know & 14 & 18 & 22 \\
Total & 100 & 100 & 100 \\
Mean & 4.1 & 4.5 & 4.6 \\
\hline
\end{tabular}




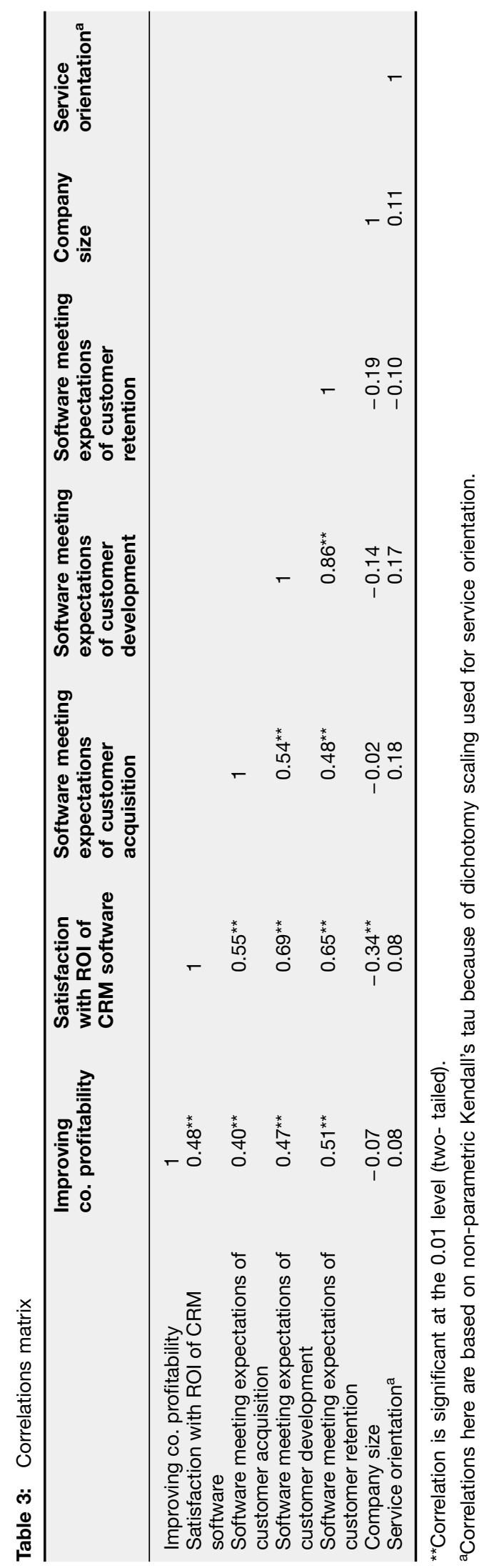

improvement) into $z$-scores. We then employed step-wise regression, thereby reducing multi-collinearity.

The results show that that the only significant predictor of company profitability is the performance of CRM software in meeting companies' expectations of customer retention $(t=3.62, p<0.001)$. All the other independent variables were insignificantly correlated with improvements in profitability. This single-factor model is significant $(\mathrm{F}=13.1, p<0.05)$ and accounts for about 30 per cent of the variance of the dependent variable (adjusted $R$-square $=0.295)$.

In $\mathrm{H} 3$, and $\mathrm{H} 4$, we hypothesised that larger companies would be more likely to deploy CRM software to assist them in customer acquisition, retention and development than smaller companies, but would be less satisfied with the ROI delivered by the software.

To test these, we ran three chi-square tests to see if there was a relationship between company size and the extent to which the three marketing activities of customer acquisition, retention and development are supported by the software. Across the three marketing activities, all chi-square values show no statistically significant differences (acquisition, $\chi^{2}=1.10$, $p>0.05$; retention, $\chi^{2}=1.34, p>0.05$; development, $\left.\chi^{2}=0.50, p>0.05\right)$. In other words, company size is not associated with the adoption of CRM software for these three customer management activities. Hence, $\mathrm{H} 3$ is not supported. But we have found evidence to support H4. From Table 3, we can see that the larger the company, the less satisfied they are with the ROI delivered by the CRM software $(r=-0.34, p<0.01)$.

In $\mathrm{H} 5$, we hypothesised that service companies would be significantly more likely to use CRM software to assist in customer acquisition, retention and development than non-service companies.

To test this hypothesis, we first divided the sample into two groups: (1) those companies 
that are in the service sector $(n=116)$ (ie, ANZSIC codes for accommodation and cafés, communication services, construction, culture and recreational services, finance and insurance, health and community services, personal and other services, property and business services, retail and wholesale trade, transport and storage, electricity, gas and water, government and education) versus (2) those that are not $(n=53)$ (ie, ANZSIC codes for manufacturing, mining, agriculture, forestry and fishing).

We found support for H5. Service companies are significantly more likely to use CRM software to assist in their customer management activities than nonservice companies. Since these two variables are nominally scaled, we tested $\mathrm{H} 5$ using non-parametric chi-square and Kendall's tau correlation. Service companies show up as significantly more likely to deploy CRM software for all three activities: acquisition $\left(r=0.24, p<0.05 ; \chi^{2}=9.3, p<0.005\right)$, retention $\left(r=0.26, p<0.0001 ; \chi^{2}=11.6\right.$, $p<0.001)$ and development $(r=0.23$, $\left.p<0.0001 ; \chi^{2}=8.9, p<0.005\right)$.

In H6, we hypothesised that service companies would be more satisfied with the ROI delivered by CRM software than non-service companies. Since one variable is categorised as a dichotomy (service or non-service), but ROI satisfaction is not, we recoded the 7-point scale of the latter into a dichotomy, where ' 1 ' represents 1 to 4 , and ' 2 ' represents 5 to 7 . We then tested this hypothesis running non-parametric (Kendall's tau) correlations between the two variables. Table 3 shows this relationship to be statistically non-significant $(r=0.08$; $p>0.05) .{ }^{50} \mathrm{H} 6$ is thus not supported.

\section{DISCUSSION}

Our research yields three major insights. First, we found that although less than 40 per cent of Australian companies use any form of CRM software to support their customer management activities, the CRM software is not equally applied across all three customer management activities acquisition, retention and development. Australian companies use CRM software more extensively to support customer retention and development, rather than customer acquisition activities. Furthermore, they are also more satisfied when the software is used for retention and development purposes. Software applications normally associated with customer acquisition are lead generation, lead qualification, market segmentation and customer profiling applications. It appears that these have limited adoption.

Second, software performance (as measured relative to expectations) has a positive relationship with both ROI and company profitability. Specifically, if the expectations of the software are exceeded in the three marketing activities of acquisition, retention and development, there is greater likelihood that the respondent is satisfied with the ROI (supporting H1), and this in turn correlates with improvements in company profitability (supporting $\mathrm{H} 2$ ). Furthermore, the software exceeding customer retention expectations is the single most important variable in explaining company profitability, accounting for about 30 per cent of its variance. This is compatible with the recent finding by Gupta et al. ${ }^{51}$ that customer retention is the most effective way of increasing the value of the company. They computed that a 1 per cent improvement in retention leads to 5 per cent improvement in firm value. This is significantly better than the results from a number of alternative strategies, including improvement in margin, reduction in customer acquisition cost and adjustments to the discount rate or cost of capital. ${ }^{52,53}$

Third, Table 3 shows that company size has a negative relationship with ROI. That is, the larger the company, the more likely it is to be dissatisfied with the ROI delivered by the CRM software (supporting H4). The implication for software and solutions vendors is to pay special attention to larger 
companies since they are more likely to be dissatisfied. Surprisingly, smaller companies are just as likely as larger companies to adopt CRM software (rejecting H3). We suspect that reduced software costs and access to hosted solutions mean that CRM is no longer the privilege of larger corporations. Indeed, evidence from several sources suggests many SMEs are now adopting CRM systems. ${ }^{54,55}$

We found that although service companies are more likely to use CRM software to assist them in their customer management activities (supporting H5), there is no significant difference in their satisfaction with ROI compared to nonservice companies (rejecting H6). Possible reasons for this finding are that service companies may have higher expectations of their CRM software, or that the software in a service environment may be more difficult to deploy.

\section{LIMITATIONS}

This study suffers from a number of limitations. First, we only reported satisfaction with the delivered ROI, rather than the ROI itself. Similarly, we did not objectively measure improvements in company profitability, but relied on respondent self-reporting. Second, we did not measure how much experience companies had accumulated with their CRM software. Likewise we do not know the amount each had invested. Third, we did not measure organisational factors (eg process excellence, training or top management buy-in) that could potentially act as barriers or facilitators to the software performance. All these factors could potentially influence the level of satisfaction level with the ROI.

\section{CONCLUSION AND PRACTICAL IMPLICATIONS}

The deployment of CRM software in Australian industry is far from mature, whether employed for customer acquisition, retention or development purposes. A number of managerial implications flow from this research. First, companies need to ensure that their investments in CRM software will achieve desired goals across the three-stage customer lifecycle: customer acquisition, retention and development. The more each of these goals is enhanced by the deployment of CRM software, the more satisfied companies will be with their investment. Second, of the three lifecycle stages, customer retention seems to be most strongly associated with managers' reporting of improved company profitability. To gain credibility, CRM software vendors must demonstrate convincingly that the software will assist in customer acquisition, retention and development, with greater emphasis on customer retention. Finally, vendors should note larger companies may be more difficult to satisfy with their CRM deployment than smaller companies. This may be simply because larger companies have higher expectations by virtue of the fact that they tend to spend more. Indeed, a recent report found that companies who spent an average of $\$ 4.4$ million on their CRM deployment were more likely to agree with the statement 'CRM deserves the bad press it has often received' than companies who spent an average of only $\$ 2.0$ million. ${ }^{56}$

On a concluding note, one could perhaps look at the Royal Bank of Canada (RBC) as a model of CRM excellence. RBC has enjoyed considerable ROI from its CRM deployment.

A model of excellence is the winner of the first international CRM Industry awards, the Royal Bank of Canada. Their CRM journey began in 1995 and has cost them over $\$ 100$ million. Today, the VP for CRM claims that 'we no longer view CRM as a program. [It] is our core strategy'. Revenue growth is running at 10-15 per cent p.a. and profit growth approaches 25 per cent p.a. 'We absolutely conclude that CRM is paying us back in spades. It has enabled us to grow both the top of house revenue line and at the same time achieve huge cost savings.' Among the ROI indicators that RBC employ are Internal Rate of Return for investments 
in major CRM functionality or initiatives such as a new pricing strategy. They also track measures such as deposit rates, credit limits, direct mail response rates, experimentally testing new tactics on subsets of customers before rolling them out across the chosen customer segments. The Bank also focuses on major metrics such as revenue growth, profit growth, cost control, risk, and debt write-offs. The Bank also credits CRM with reducing the costs of acquiring each dollar of revenue from 63 to 55 cents.

\section{References and Notes}

1 Payton, F. and Zahay, D. (2003) 'Understanding why marketing does not use the corporate data warehouse for CRM applications', Journal of Database Marketing, Vol. 10, No. 4, pp. 315-326.

2 Buttle, F 2004 'Customer relationship management: Concepts and tools', Elsevier Butterworth Heinemann, Oxford.

3 Knox, S., Maklan, S., Payne, A., Peppard, J. and Ryals, L. (2002) 'Customer relationship management: Perspectives from the marketplace', Elsevier Butterworth Heinemann, Oxford.

4 Yu, L. (2001) 'Successful customer relationship management', MIT Sloan Management Review, Vol. 42, No. 4, pp. 18-19.

5 Wilson, H., Daniel, E. and McDonald, M. (2002) 'Factors for success in customer relationship management (CRM)', Journal of Marketing Management, Vol. 18, pp. 193-219.

6 Gartner Group (The) (2003) 'Asia/Pacific: An insight into complex dynamics', available at http://www4. gartner.com/Init(accessed 16th June 2004).

7 eMarketer (2005) 'CRM spending and trends,' available at www.emarketer.com(accessed July, 2006).

8 Gartner Group (The) (2005) 'Hype Cycle, available at http://www3.gartner.com/research/focus_areas/ asset_48253.jsp\#Hype_Cycles(accessed 10th February 2005).

9 eMarketer (2005) op cit.

10 Sweat, J. (2002) 'When CRM failure isn't', available at http://www.crmguru.com/features/2002b/0516js. html(accessed 16th June 2004).

11 Paas, L. and Kuijlen, T. (2001) 'Towards a general definition of customer relationship management', Journal of Database Marketing, Vol. 9, No. 1, pp. 51-60.

12 Agarwal, A., Harding, D. and Schumacher, J. (2004) 'Organising for CRM', McKinsey Quarterly, Vol. 3, pp. 80-91.

13 Iriana, R. and Buttle, F. (2006) 'The impact of organizational culture on customer relationship management outcomes' International Journal of Knowledge, Culture and Change Management, Vol. 6, No. 2, pp. 137-148.

14 Marketing Science Institute (2005) 'Research priorities for the customer management community,available at http://www.msi.org/msi/ rp0406.cfm\#RP-Overview(Accessed 25th July 2005).

15 Rackham, N. (2000) 'Learn from past mistakes', Sales and Marketing Management, Vol. 152, No. 12, pp. 38-39.

16 Holt, S. (1998) 'Sales force automation ramps up', Info World, Vol. 20, pp. 12, 29-31.
17 Schafer, S. (1997) 'Supercharged Sell', Technology Supplement', Vol. 19, pp. 42-52.

18 Stein, T. (1998) 'Software for the hard sell — by adding functionality, sales force automation systems are overcoming a bad reputation', Information Week, Vol. 671, pp. 18-19.

19 Blodgett, M. (1995-96) Vendor tries to simplify sales force automation, Computerworld, Vol. 30, No. 1, p. 62 .

20 Erffmeyer, R. C. and Johnson, D. A. (2001) An exploratory study of sales force automation practices: Expectations and realities, Journal of Personal Selling and Sales Management, Vol. 21, No. 2 (Spring), pp. 167-175.

21 Speier, C. and Venkatesh, V. (2002) 'The hidden mindfields in the adoption of sales force automation technologies', Journal of Marketing, Vol. 66, pp. 98-111.

22 Bush, A., Moore, J. and Rocco, R. (2005) 'Understanding sales force automation outcomes: A managerial perspective', Industrial Marketing Management, Vol. 34, No. 4 (May), pp. 369-377.

23 See for exampleDoyle, S. (2002) 'Software review: Rules-based engines or statistical optimisation: The intelligent way forward', Journal of Database Marketing, Vol. 10, No. 1, pp. 85-89.

24 See for examplePleasants, N. (2002) 'Getting the most out of contact management software', Journal of Database Marketing, Vol. 9, No. 4, pp. 360-365.

25 Light, B. (2003) 'CRM packaged software: A study of organisational experiences,' Business Process Management Journal, Vol. 9, No. 5, pp. 603-616.

26 Jayachandran, S., Sharma, S., Kaufman, P. and Raman, P. (2005) 'The role of relational information processes and technology use in customer relationship management', Journal of Marketing, Vol. 69, pp. 177-192.

27 Reinartz, W., Krafft, M. and Hoyer, W. (2004) 'The customer relationship management process: Its measurement and impact on performance', Journal of Marketing Research, Vol. 41, No. 3, August, pp. 293-305.

28 Reinartz, W., Krafft, M. and Hoyer, W. (2004) ibid.

29 Jayachandran, S., Sharma, S., Kaufman, P. and Raman, P. (2005) op cit.

30 Reinartz, W., Krafft, M. and Hoyer, W. (2004) op cit.

31 Rigby, D. (2003) 'Management tools survey, 2003: Usage up as companies strive to make headway in tough times', Strategy and Leadership, Vol. 31, No. 5, pp. 4-11.

32 eMarketer (2005) op cit.

33 Bull, C. (2003) 'Strategic issues in Customer Relationship Management (CRM) implementation', Business Process Management Journal, Vol. 9, No. 5, pp. 592-602.

34 Starkey, M. and Woodcock, N. (2002) 'CRM systems: Necessary but not sufficient. REAP the benefits of customer management', Journal of Database Marketing, Vol. 9, No. 3, pp. 267-275.

35 Woodcock, N. (2000) 'Does CRM performance correlate with business performance?' The Journal of Interactive Marketing, Vol. 1, (April/June), p. 4. 
36 Erffmeyer, R. C. and Johnson, D. A. (2001) op cit.

37 Bush, A., Moore, J. and Rocco, R. (2005) op cit.

38 Engle, R. and Barnes, M. (2000) 'Sales force automation usage, effectiveness, and cost-benefit in Germany, England and the United States', Journal of Business and Industrial Marketing, Vol. 15, No. 4, pp. 216-242.

39 Gillan, C. (1992) 'White paper: Sales force automation', Sales and Marketing Management, Vol. 144 (December), pp. 19-30.

40 Wright, G. and Donaldson, B. (2002) 'Sales information systems in the UK financial services industry: An analysis of sophistication of use and perceived barriers to adoption', International Journal of Information Management, Vol. 22, pp. 405-419.

41 Starkey, M., Williams, D. and Stone, M. (2002) 'The state of customer management performance in Malaysia', Marketing Intelligence and Planning, Vol. 20, No. 6, pp. 378-385.

42 Ang, L. and Buttle, F. (2002) Industrial marketing and purchasing, Perth, Australia. ROI in CRM: a customer journey approach. Proceedings of the Inaugural Meeting of the IMP group in Asia, 'Culture and Collaboration in Distribution Networks', Perth, Australia, December; ISBN 1 740671848

43 Gupta, S., Lehmann, D. and Stuart, J. A. (2004) 'Valuing customers', Journal of Marketing Research, Vol. XLI, (February), pp. 7-18.

44 Rivers, M. L. and Dart, J. (1999) 'The acquisition and use of sales force automation by mid-sized manufacturers', Journal of Personal Selling and Sales Management, Vol. 19, No. 2, pp. 59-73.

45 Starkey, M. and Woodcock, N. (2002) op cit.

46 Rigby, D (2003) op cit.
47 Hendricks, K. B. and Singhal, V. R. (2000)

'Implementing effective total quality control (TQM) programs and financial performance: A synthesis of evidence from quality award winners', in: Kochan, T., Levine, D., Olson, C. and Strauss, G (Eds.) 'What works at work - The bottom line implication of workplace practices', Cambridge University Press, Cambridge, pp. 234-272.

48 Zeithaml, V. A. and Bitner, Mary Jo. (2003) 'Services marketing', 3rd Edition, Irwin McGraw Hill, Singapore.

49 Starkey, M. and Woodcock, N. (2002) op cit.

50 We adopted non-parametric tests because our preliminary analysis showed that the assumptions of normality and homogeneity of variance were violated when we compared service versus nonservice companies on their satisfaction of their ROI. However, Even if one were to ignore these violations, one-way ANOVA tests revealed nonsignificant results similar to those reported in Table 3.

51 Gupta, S., Lehmann, D. and Stuart, J. A. (2004) op cit.

52 See also Reichheld, F. (1996) 'The loyalty effect: The hidden force behind growth, profits, and lasting value', Harvard Business School Press, Boston.

53 Reinartz, W. and Kumar, V. (2000) 'On the profitability of long-life customers in a noncontractual setting: An empirical investigation and implications for marketing', Journal of Marketing, Vol. 64(October), pp. 17-35.

54 Buttle, F. (2006) Hosted CRM: Literature Review and Research Questions, Working Paper \# 2006-1, Macquarie Graduate School of Management, Sydney, Australia.

55 eMarketer (2005), op cit.

56 eMarketer (2005) op cit.

\section{Appendix}

1. Which of the following customer management activities are supported by CRM software?

Yes No

Customer acquisition 11

$\begin{array}{lll}\text { Customer development } & 1 & 2 \\ \text { Customer retention } & 1 & 2\end{array}$

2. Overall, how would you rate your satisfaction with the return on investment from your use of this CRM software? (Please check 'Don't Know' if you don't know or are not sure)

Not at all satisfied

$1 \quad 2 \quad 3$

3. Now, thinking about customer acquisition, customer retention and customer development in turn, to what extent has the software met your expectations? (Please check 'Don't Know' if you don't know or are not sure)

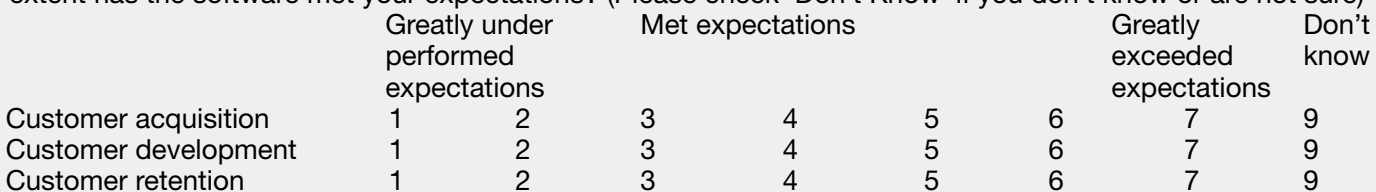

4. Using the scale from 1 to 7 , circle the number that best reflects the contribution that your CRM implementation has made to improved company profitability. No contribution

Improved company

1

2

3

4

Critical profitability 